\title{
Neuromarketing and its implications for operations management: an experiment with two brands of beer
}

\section{Neuromarketing e suas implicações para a gestão de operações: um experimento com duas marcas de cerveja}

\author{
Jorge Henrique Caldeira de Oliveira' ${ }^{1}$ (D) \\ Janaina de Moura Engracia Giraldi' ${ }^{1}$ (])
}

How to cite: Oliveira, J. H. C., \& Giraldi, J. M. E. (2019). Neuromarketing and its implications for operations management: an experiment with two brands of beer. Gestão \& Produção, 26(3), e3512. https://doi.org/10.1590/0104-530X3512-19

\begin{abstract}
Neuromarketing and neurophysiology of consumer behavior and sensory experiences are growing in research results and importance to the operations activities due to the possibility of designing products and processes that are more suitable to the consumers' needs. In addition, there is a wide range of applications on the shop floor, such as safety design, man-machine design and other applications related with cognitive processing and its impact on human behavior. This article discusses the impact of advertising of recognized brands on the visual selective attention of young adults in the consumption of alcoholic beverages. The discussion considered the model of dual cognitive processing, in which prolonged effects of exposure to brands with strong positive associations would result in increased selective attention and commitment to strong brands. An experiment with two brands of beer using an eye-tracking equipment to identify the patterns of visual attention was carried out. The results showed that there are considerable differences in young adults for visual attention, with greater attention to strong brands. The study may help to develop more effective marketing campaigns and products, providing the consumers a better experience. Furthermore, it also allows for a better comprehension on attention at the workplace, providing important insights in several areas of production, such as work safety, repetitive processes, equipment handling among others.
\end{abstract}

Keywords: Operations; Selective attention; Dual cognitive processing; Branding; Eye-tracking.

Resumo: A neurofisiologia do comportamento do consumidor e as experiências sensoriais estão crescendo em resultados de pesquisa e importância para as atividades operacionais devido à possibilidade de projetar produtos e processos mais adequados às necessidades dos consumidores. Além disso, há uma grande variedade de aplicações no chão de fábrica, como projetos de segurança, de interação homem-máquina e outras aplicações relacionadas com o processamento cognitivo e seus impactos no comportamento humano. Este artigo discute o impacto de anúncios de marcas reconhecidas na atenção visual seletiva de jovens adultos no consumo de bebidas alcoólicas. A discussão considerou o modelo de processamento cognitivo duplo, no qual efeitos prolongados de exposição a marcas com fortes associações positivas resultariam em maior atenção seletiva e comprometimento com marcas fortes. Foi realizada um experimento com duas marcas de cerveja utilizando um equipamento de rastreamento ocular (eye-tracking) para identificar os padrões de atenção visual. Os resultados mostraram que há diferenças consideráveis em adultos jovens na atenção visual, com maior atenção para marcas fortes. Este estudo pode ajudar a desenvolver campanhas de marketing e produtos mais eficazes, proporcionando aos consumidores uma melhor experiência. Adicionalmente, este estudo permite uma melhor compreensão sobre atenção no ambiente de trabalho e gera importantes reflexões em diversas áreas da produção, como advertências e segurança no trabalho, processos repetitivos, manuseio de equipamentos entre outras aplicações.

Palavras-chave: Operações; Atenção seletiva; Processamento cognitivo duplo; Branding; Rastreamento ocular.

\section{Introduction}

Considering the ever increasing customer demands and decreasing product life cycles, the application of neuromarketing and cognitive neuroscience

tools are of great interest for the production and operations management, once the operations function need marketing and brand information to determine

${ }^{1}$ Universidade de São Paulo - USP, Av. Bandeirantes, 3900, Monte Alegre, CEP 14040-905, Ribeirão Preto, SP, Brasil, e-mail: jorgecaldeira@usp.br; jgiraldi@usp.br 
production capacity, and to set finance and human resources decisions. Since marketing can be considered to be at the interface between the organization and the environment, marketing and thus neuromarketing research can provide new opportunities for value creation and growth, by identifying opportunities to serve unmet needs of current customers or new customers for the company's current and new products and services (Wind, 2005).

Neuromarketing research is becoming increasingly important, since Achrol \& Kotler (2012) has indicated that consumers go about need satisfaction via a complex of experiences filtered through their senses. These senses include the visual (perceptual), auditory and olfactory senses, the sense of taste, the sense of touch and feel (tactile and haptic sense), the sense of limb position and motion (proprioception and kinesthesis) and finally the sense of whole-body orientation and motion (vestibular sense). In this regard, neurophysiology of consumer behavior and sensory experiences are growing in research results and importance to the operations activities.

In addition, the findings of neuromarketing and cognitive neuroscience have enormous potential to bring insight into the production management, such as: human behavior, the mental workload of a machine operator, the level of attention devoted over time by factory workers, the cognitive processes involved in human errors that generate work accidents, fatigue compensation models, levels of visual attention and error reading of warnings in safety equipment, analysis of mental activity during processes (Parasuraman \& Wilson, 2008; Ma et al., 2012a, b). All these areas of interest to the Production and Operation field can be approached by neuromarketing tools. Another potential application is related to the development of more ergonomic products and processes. In this line, neuromarketing can increasingly assist in the understanding of usability, whether of the final product or its production (Fafrowicz \& Marek, 2007; Parasuraman \& Wilson, 2008).

The literature has demonstrated the potential of eye-tracking for neuromarketing research and for the development of marketing strategies and planning in general (Solnais et al., 2013). The use of eye-tracking and other neuromarketing tools in marketing analysis is becoming increasingly popular and shows great potential for aiding market research, innovation, product development, advertising, sales, customer service, loyalty programs, and various other marketing topics (Santos et al., 2015).

Specifically about using eye-tracking in the evaluation and planning of a brand, this method may contribute to the definition of the brand elements by testing with potential consumers and identifying drivers that cause more visual impact (Santos et al., 2015). Since a brand is a world of attractions and desires for consumers, it should be dynamic, active, and present in the life and mind of a consumer, stimulating their brain and generating emotions (Martinez, 2011). Nonetheless, attracting a consumer's visual attention is increasingly more difficult, considering the vast volume of available advertisements (Wedel \& Pieters, 2000; Winer, 2009).

To Keller (2009), anything that could cause the consumer to notice and pay attention to the brand could lead to increased brand awareness, which is one component of brand knowledge. Brand awareness is related to the strength of the brand node or trace in memory as reflected by consumers' ability to recall or recognize the brand under different conditions (Keller, 2009). Increased brand knowledge by marketing programs and activities is a fundamental requirement for increasing brand equity.

Brand equity relates to the fact that different outcomes result in the marketing of a product or service because of its brand, as compared to if that same product or service was not identified by that brand (Keller, 2009). Thus, companies build their brand equity by creating brand knowledge structures with the target audience. Three major brand equity drivers can be categorized as: initial choices of brand elements (brand name, logos, symbols, characters, representatives, slogans, jingles, packaging, and signs); the product, the service, and all associated marketing activities and support marketing programs; and, finally, other associations indirectly transferred to the brand (Kotler \& Keller, 2009).

Considering that one of the aims advertising is to influence consumer memory and attitudes in order to build strong brand equity, it is important to understand how consumers process information available on the brands. Consumers exposed to marketing communications can rely on peripheral cues and process information heuristically. Alternatively, they can take a central route and process information systematically, which may lead to attitude change (Samson \& Voyer, 2012).

Samson \& Voyer (2012) indicate that, over the last two decades, psychologists have distinguished between these two systems of thought with different capacities and processes, referring to them as System 1 and System 2. System 1 consists of high-capacity intuitive thoughts, whereas System 2 involves low capacity reflective thinking.

In this respect, the dual cognitive processing model discusses the role of intuition and the unconscious in decision making, in general and applied to the choice of a brand. This model is of great interest for studies on purchasing behavior and decision making because it discusses and seeks to categorize and understand the situations in which it is more common for the human brain to act intuitively in a decision making process. Moreover, situations in which intuition 
is not the most natural way are also categorized, according to this model (Kahneman, 2011). This line of studies allows shedding new light on the quality of consumption decision making when processed in each of these modes (System 1 and System 2).

To Samson \& Voyer (2012), consumers evaluate products by relying on easily accessible information in memory or affect (System 1) or process information reflectively by weighing up costs and benefits (System 2). The level of consciousness for the selection of products or services can potentially bring new answers about consumer behavior and increase the predictability of their actions.

In this context, a significant gap still remains in the literature: what is the impact of dual cognitive processing of selective attention when strong brands are compared to weak brands in terms of visual attention? This paper seeks to answer this question by means of a neuromarketing tool; the eye-tracking equipment. These answers may help the operations function to receive better information concerning consumers' evaluation of brands, making it possible to design products and processes that are more suitable to the consumers' needs. Moreover, as exposed by Samson \& Voyer (2012), duality of mind research can be expected to benefit from advances in neuroscience, offering more supporting evidence for a dissociation of System 1 and System 2.

\section{The Model of Dual Cognitive Processing and marketing communications}

The amount of daily information that consumers are exposed to is monumental and has grown exponentially in recent decades, while traditional marketing surveys are becoming increasingly less effective (Barkin, 2013; Ait Hammou et al., 2013; Solnais et al., 2013; Sreedevi et al., 2013). Stimuli are increasingly intensified, either visual, olfactory and mostly auditory. One of the consequences is the increasingly difficult of companies in positioning their brands effectively to different groups and understanding the real existing distinctions (Venkatraman et al., 2012).

Thus, marketing and advertising practices could be improved by allowing for the effective two-way processing of product-related information (Samson $\&$ Voyer, 2012). System 1 corresponds to a "fast track" in decision making (when decision making is done quickly). System 2 refers to a much slower cognitive processing based on superior reasoning and on analyses consistent with those recommended by utility maximization models, characteristic of classical economic models (Evans, 2008).

There is a physiological reason for the brain structure: System 1 allowed saving cerebral processing energy, thereby providing better quality for analyses of System 2. From the moment in which decision making is linked to System 1, the processing starts being automatic and unconscious. Other important features in System 1 referring to consciousness is that it is a standard processing that requires little brain effort, since an intuitive and quick analysis will be adopted. Therefore, System 1 would be linked to unconscious cognition, being responsible for the control of many of our behaviors, even not being aware of it (Barrett et al., 2004; Evans, 2008).

At the same time, System 1 differs from System 2 because it is slow and has limited processing capacity. Many decisions that are important and directly or indirectly impact the quality of life of people may actually be based on System 1, which may represent some potential problems about the quality of those decisions. When we think about an issue " $X$ " and rationally measure the results of different actions, this does not necessarily mean that when we are faced with a situation in which issue " $X$ " is present, we are effectively making the decision that maximizes utility. In other words, System 2 makes us think we are in control, and often System 1 is in control (Strack $\&$ Deutsch, 2004; Toates, 2006).

One of the reasons for this to occur is the associative relationship rather than that rule-based as functional feature in System 1. The associative effect is something quite powerful in the unconscious, as it will generate strong, positive and negative links. This link may have a long-term association or not. For example, placing together the words "egg" and "vomiting", during the few seconds of reading these words, one will associate unpleasant images and memories of the second word, but this association can be made for some time with the first word. That is, when we think of eggs, we will link feelings of revulsion and disgust associated with vomiting. This effect is linked to System 1 and is therefore automatic and involuntary. Eventually, this association will be overcome because it is not a strong association for most people, but for others, it may be intense and long lasting (Sloman, 1996; Smith \& DeCoster, 2000).

These words associations are of great interest to the field of marketing, since various purchasing decisions, if based on System 1, may be decided in milliseconds, for example, when the customer is in front of a supermarket shelf with several brands. For being automatic, the association leads the customer to like or not a product due to unconscious relations with other situations without direct links to the product in question. For example, good memories experienced about the consumption of a product or unpleasant situations would bring, through this mechanism, a strong incentive for the consumption or not of a specific brand. Rational aspects can potentially be relegated to a second plan on purchasing decisions. 
In seeking to attract the target audience for their products and services, companies compete every second for the attention of such potential customers. A way that has become common with increased competition is to influence children as a way of ensuring that future and potential consumers effectively have a strong perception of the company's brand rather than that of its competitors. This strategy may elicit clear ethical problems (Bao et al., 2007; Fournier, 1998; Moore, 2004; Auty \& Lewis, 2004; Ülger \& Ülger, 2012).

Nairn \& Fine (2008) expose ethical concerns of advertisement for children and its possible implications on consumption decisions in adolescence and early adulthood. The authors seek to identify some consequences of dual cognitive processing for the formation of consumer's behavior and perception of brands. Their main argument is that the findings of dual cognitive processing in neuroscience shed new light on the behavior and perceptions of young adults and, later, throughout the adult life of these individuals. The implicit association in System 1 of the Model of Dual Cognitive Processing in the brain occurs in childhood through advertisements with positive stimuli, even though these advertisements have an explicit focus of reaching only adults (Nairn \& Fine, 2008).

One of the consequences of processing on System 1 that is of interest in this research refers to brand equity formation. According to Yoo \& Donthu (2001), there is considerable debate regarding the definition of brand equity and its measurement, but it is accepted as the overall utility that customers place in a brand in comparison to its competitors (Chernatony \& McDonald, 2003).

\section{Neuromarketing tools to study the Model of Dual Cognitive Processing}

Although the findings of dual cognitive processing are relatively new, there are many studies that show interest in the understanding the role of brands in the process of consumers decision-making under different neuroscientific aspects. Through the lens of neuroscience, these studies tried to understand some brand equity components and preference and loyalty to one brand over the others (Deppe et al., 2005a, b, 2007; Esch et al., 2012; Hillenbrand et al., 2013; McClure et al., 2004; Plassman et al., 2007; Ratnayake et al., 2010; Reimann et al., 2012a, b; Santos et al., 2011; Schaefer et al., 2006; Schaefer $\&$ Rotte, 2007a, b).

One study of particular interest for this research is the one performed by Esch et al. (2012). Seeking to understand the effect of brand equity on the human brain, they used Functional Magnetic Resonance
Imaging (fMRI) to identify aspects that go beyond brand consciousness and its consequent conscious cognitive association. These aspects go also beyond mental coding and recovery that are rational and conscious of brand attributes and knowledge on the brand during processing and evaluation of alternative brands in a decision making process. Brands also evoke feelings and physical and visceral emotions related to implicit and unconsciousness of System 1 within the logics of understanding of the dual cognitive processing.

In their results, MRI identified a strong activation of the insula, when participants were exposed to weak brands, comparing to strong brands. The insula is a brain region that has extensive connections with other regions linked to emotion, such as the amygdala, for example. Furthermore, the insula is associated with negative feelings, pain and risk decisions. On the other hand, strong brands strongly activate the right and left hemispheres of the paladium, which is associated with pleasurable experiences and positive emotions associated with sensory stimuli. Therefore, one of the most important conclusions is that the evaluation of brands (strong and weak) did not occur in the brain through cold and analytical processing, but unconsciously, with positive or negative emotions (Esch et al., 2012).

Given these characteristics of positive and negative emotions linked to strong and weak brands in the unconscious, this research questions if young adults already show these emotional effects. Moreover, the study of visual attention given to strong and weak brands has received little attention. The importance of vision for neuroscience can be assessed by the proportion of space in the brain designated for the visual processing of images and their associations: $25 \%$ of its volume is dedicated to this purpose (Zurawicki, 2010). However, little is known about the impacts of brands on the visual attention behavior, as seen next.

Some studies have obtained important results on visual neuroscience for brand equity. Plassmann et al. (2012) reported that the visual system and the capacity of brain devoted to vision allow quick identification of brands. More importantly, Junghöfer et al. (2010) demonstrated, by using Magnetoencephalography (MEG) for measuring brain responses, that images of products with gender appeal guide visual attention and selectively generate neural response quicker than neutral images or those without gender appeal. Exposing women and men to images of shoes and motorcycles and to neutral images (landscapes), researchers identified a significant speed, 130 and 180 milliseconds (ms), for all women included in the experiment to have a strong reaction in the neural processing in brain areas devoted to vision (occipito-temporo-parietal regions). This almost instantaneity represents opportunities 
and challenges for marketing, and particularly for visual communication.

Where visual attention focuses to acquire information from visual stimuli can also be unconscious and not only conscious, as expected in the majority of attention models. In general, traditional marketing assumes that selective visual attention is a bottom-up process. In this process, automatic filters select the visual information from an amount of visual stimulus information. In this case, characteristics such as shape, size, motion, luminance and color, for example, are given as the most important aspects for visual selection. However, a new focus, based on top-down unconscious processing came to be contemplated in some studies (Chartrand et al., 2008; Fitzsimons et al., 2002). Considering all the findings, it could be inferred that the same unconscious and extremely quick brain processing effects associated with peripheral vision, eventually allow selective attention to seek stronger and recognized brands more quickly than weaker brands.

Despite the great importance of visual attention for marketing and the better understanding of brand equity for organizational strategies, few works have discussed about brands, primarily manipulating sensory variables, seeking implicit associations or trying to understand conscious aspects of visual attention (Siefert et al., 2008; Stewart et al., 2004; Theeuwes, 2010). None of these papers deal with the relationship of visual attention and differences between strong and weak brands.

Therefore, there is a significant gap in studies that seek to understand standards of visual attention related to brand equity. In addition, there are ethical questions raised by Nairn \& Fine (2008), who discuss consumption among children and young people, as well as recent discoveries of Esch et al. (2012) and Junghöfer et al. (2010) about brand equity and unconscious emotions linked to the dual cognitive processing. As a result of these works, there is a theoretical framework of multidisciplinary scientific discoveries that underlie the present work and that have not received enough attention in academia.

\section{Experimental methods}

In order to obtain the results and based on previous researchers (Kent \& Allen, 1994; Wedel \& Pieters, 2000; Chandon, 2002; Hoeffler \& Keller, 2003), the following hypotheses have been verified in this research:

- H1: The time from start of visual stimuli until the moment the individual fixes the visual attention in the brand will be slower in a strong brand in comparison to a weak brand;
- H2: The fixation of visual attention in other areas not related to the brand (logo or brand name) before fixation on the brand itself will be slower on strong brands in comparison to weak brands;

- H3: The total duration of time devoted by each individual for areas linked to strong brand in the set of images shown will be faster than the total duration of time devoted by each individual to areas linked the weak brand.

Selective visual attention can be defined as the mechanism responsible for selecting information that gains preferential status over other available information (Plassmann et al., 2012). The capture of visual attention was performed with equipment Tobii Eye Tracker hardware model X1L with data capture at $30 \mathrm{~Hz}$, i.e., averaging 30 captures of sample per second (by eye), with dual-camera system for tracking both eyes and automatic selection of light and dark for pupil tracking. The tracking recovery time after an eye blink is of $10 \mathrm{~ms}$.

For data analysis, two programs were used: the system for eye-tracking image processing called Studio Professional 3.2 was firstly used; subsequently the SPSS 17.0 was used. Standard images presented to all participants were processed and AOI filters were applied. An AOI (Area of Interest) is a region of the image selected in a discretionary manner to meet the research objectives. Four images were displayed for 7 seconds each, two advertisements of a strong brand and two of a weak brand according to criteria detailed in the next section. The AOI defines the region of the stimulus in which the research has interest in creating filters and understanding the visual attention behaviors. The processing of data created in these pre-determined regions were the basis to quantitatively understand the representation of participants' visual attention.

\subsection{Criteria for the selection of visual stimuli and participants}

To achieve the main objective of this research, we sought a specific selection of visual stimuli, considering (1) sector of activity, (2) selection of brand (strong and weak) and (3) selection of printed advertising with similar characteristics. As the goal is to analyze how a strong brand impacts differently compared to a weak brand in the way of affecting selective attention and visual processing in the minds of young consumers, the selection of participants and visual stimuli demanded very careful criteria.

In the discussion of the research problem, the ethical concern for the impact of advertisements on children and adolescents stood out (Nairn \& Fine, 2008). 
One possibility, increasingly studied by neuroscience, is that the role of these advertisements on the Dual Cognitive Processing in the brain has strong development early in life and consequently impacts the decision making in the early adulthood of young consumers (Esch et al., 2012).

In this context, the sector of alcoholic beverages (beer) was chosen, because it gathers the main concerns of Corporate Social Responsibility and responsible consumption, for two main reasons: negative consequences for society of irresponsible alcohol consumption and the high level of marketing investments made by the beer industry worldwide.

Epidemiological studies have shown that alcohol consumption is associated with various types of diseases, including cancer. Several types of cancer seem to be linked to the regular and especially excessive consumption of alcoholic beverages, especially oral, larynx, esophagus, liver, colon and rectum cancer. Other studies have shown a link between alcohol and pancreatic and lung cancer (Boffetta \& Hashibe, 2006; Pöschl \& Seitz, 2004). Alcohol is also linked to dozens of other health hazards, such as heart disease and stroke. The World Health Organization (WHO) estimates that $4 \%$ of all deaths worldwide are related to alcohol consumption (Cortez-Pinto et al., 2010).

The experiment was held in Brazil, a country that has one of the highest per capita consumers of beer in the world Besides, it does not have a policy restricting advertisement on alcohol consumption and the alcoholic beverages sector is among the top ten investors in advertising in Brazil, with annual investment greater than two billion dollars and has historically maintained a prominent position in this regard (IBOPE, 2012).

In the criteria for the selection of brands (strong and weak), two variables with equal weights were used: brand longevity and market share. In this study, strong and weak brands will be identified with letters S (strong) and W (weak). The variable brand longevity refers to the time of existence of the brand in the market. This criterion was chosen because one of the factors associated to reliability and quality of a brand is precisely its constancy of existence, favoring those with constant exposure to an individual from childhood, even if there is no consumption (Lindstrom, 2008). The strong brand $\mathrm{S}$ was chosen due to its existence in the Brazilian market since 1969. Weak brand $\mathrm{W}$ was chosen due to its existence since 1999.

The second variable used in the criterion for the selection of brands was market share. The implicit assumption of this choice is that the market share of the brand is a quite reasonable proxy of the perception of consumers in relation to brand equity, since the choice was made between nationwide brands with high logistic capillarity in different points of sales such as supermarkets, bars and restaurants. In this criterion, the strong brand chosen (S) was the market leader in 2012 with about 32\% share, and the weak brand chosen (W) had less than $6 \%$ share (IBOPE, 2012).

The result of the consultancy firm Millward Brown under the Brand Analytics division which annually seeks to identify the 50 most valuable brands in the country reinforces this criterion. Using the Brand $\mathrm{Z}$ model of that consultancy for brand evaluation, which seeks to identify the impact of the brand on the financial performance of companies, in 2014, the brand (S) chosen was considered the most valuable brand in the country in relation to all categories and sectors evaluated. The weak brand (W) was not included in the list of these fifty companies (BrandAnalytics, 2014).

This study selected images in which there was a relative similarity of percentage of AOIs of strong and weak brands. This step in the pre-selection of images was aimed at reducing the possibility of interference in visual attention of having more area exposed for one brand in relation to another. The measurement was made on the display screen used ( 15 "LCD monitor). This precaution was taken because measurement based on image data or any other equipment could bring distortions, since differences in technology, sharpness or resolution, image transference means (HDMI, VGA etc.) could affect image size.

Finally, in the criterion of selection of advertisements with specific AOIs, printed visual communications in which there was some similarity between the exposed areas of strong brand (S) and weak brand (W) were used, thus seeking to avoid that disproportionality would result in greater visual attention to $\mathrm{S}$ or $\mathrm{W}$. In the measurement elaborated, the total exhibition area of stimuli made was $580.74 \mathrm{~cm}^{2}$ for weak brand and $587.64 \mathrm{~cm}^{2}$ for strong brand. Therefore, differences in exposure images were very small $(<2 \%)$. More importantly was to verify this relationship for AOI of strong and weak brands.

As the example in Table 1, two visual stimuli of communication of strong brand (image S-A and image S-B) and two stimuli of weak brand (image W-A and image $\mathrm{W}-\mathrm{B}$ ) were selected. These images were showed in a random sequence. Image $\mathrm{W}$-A referring to weak brand has only one AOI, named with code AOI-W-A1. The second image of the weak brand, $\mathrm{W}-\mathrm{B}$, has three AOIs and was named with codes AOI-W-B1, AOI-W-B2 and AOI-W-B3. The first image of strong brand (image S-A) also has only one AOI, named AOI-S-A1. The second image of the 
Table 1. AOIs of strong (S) and weak brands (W).

\begin{tabular}{ccccc}
\hline AOI Code & Image/Stimulus & Width $\mathbf{( c m )}$ & Height $\mathbf{( c m )}$ & Area $\left.\mathbf{( c m}^{\mathbf{2}}\right)$ \\
\hline AOI-W-A1 & Image W-A & 2.7 & 1.4 & 3.78 \\
AOI-W-B1 & Image W-B & 3.8 & 2 & 7.6 \\
AOI-W-B2 & Image W-B & 3.2 & 1.7 & 5.44 \\
AOI-W-B3 & Image W-B & 1.4 & 0.8 & 1.12 \\
AOI-S-A1 & Image S-A & 3.0 & 1.8 & 5.4 \\
AOI-S-B1 & Image S-B & 3.8 & 1.95 & 7.41 \\
AOI-S-B2 & Image S-B & 2.8 & 1.8 & 5.04 \\
\hline
\end{tabular}

strong brand (image S-B) has two AOIs: AOI-S-B1 and AOI-S-B2.

The total exhibition area of the weak brand (W) in the experiment was $17.94 \mathrm{~cm}^{2}$, or $3.09 \%$ of total exposed images of the weak brand. The total exhibition area of the strong brand (S) in the experiment was $17.85 \mathrm{~cm}^{2}$, or $3.04 \%$ of total exposed images of the strong brand. It is believed that with these characteristics of visual stimuli presented to participants, the risk of interference in the selective visual attention analysis is decreased.

Finally, the selection of participants considered the research objectives. The proposal of analyzing young people attended the premise of the discussion presented in the introduction. It can be assumed that younger consumers would be less susceptible in the maturing of their own tastes on alcoholic beverages given to time, in years, of their consumption. Older consumers are certainly more biased and have more definitive assessments about the perceived quality of a brand that they consume for longer time. In this context, it is expected that differences in selective visual attention in this group are more representative of the impact of dual cognitive processing on brand equity, by means of visual attention.

The selection of a university environment for the selection of these young people also met the same line of arguments. University students are part of a group that consumes beer more continuously from the university entrance (Ramis et al., 2012). The age of respondents ranged from 17 to 25 years, with a total of 178 participants. The mean age was 20.58 years with standard deviation of 2.29 years. Of this group, 87 individuals were female (48.9\%) and 91 were male $(51.1 \%)$.

\section{Results}

Under the dual cognitive processing model, it was verified the potential of strong brands to bring strong and unconscious positive emotions and weak brands to be associated with negative feelings and implicit risks, which would attract or remove visual attention, respectively (Esch et al., 2012).

\subsection{Hypothesis 1}

H1 of this research was defined as: "The time from start of visual stimuli until the moment the individual fixes the visual attention in the brand will be slower in a strong brand in comparison to a weak brand". The variable analyzed was the time each individual took to have the visual attention on the strong brand or on the weak brand.

The sequence of images presented was W-A, S-A, $\mathrm{W}-\mathrm{B}$ and $\mathrm{S}-\mathrm{B}, \mathrm{W}-\mathrm{A}$ and $\mathrm{W}-\mathrm{B}$ regarding the weak brand, and S-A and S-B regarding the strong brand. As the exposure time of each image was 7 seconds, the measurement of the visual attention to the weak brand $(\mathrm{W})$ was paused at the end of the W-A presentation. If the individual in no time fixed the attention in the AOI of this image (AOI-W-A1), the time was stopped at the entrance of image S-A, since this image had only AOI related to the strong brand.

According to Table 2, there was a significant difference in the time required for an individual to initially fix on the strong brand in relation to the weak brand. Since the total analysis time was 14 seconds for each brand, the weak brand became the focus of visual attention for the first time almost at the end of the first stimulus.

Having excluded the possibility of normality through parametric Kolmogorov-Smirnov and Shapiro-Wilk tests (significance level less than 5\% in both), the non-parametric Wilcoxon test was applied to verify if the differences between these means of 3.21 seconds for the strong brand and 5.68 for the weak brand are statistically significant. The p-value was equal to 0.000 , being lower than $5 \%$ of margin imposed, validating differences. On average, participants took $77 \%$ longer to fix for the first time in the weak brand in relation to the strong brand.

\subsection{Hypothesis 2}

$\mathrm{H} 2$ of this research was defined as: "The fixation of visual attention in other areas not related to the brand (logo or brand name) before fixation on the brand itself will be slower on strong brands in comparison to weak brands". The variable analyzed in this hypothesis was the number of fixations that each 
individual has made in areas not related to AOI's of the strong and weak brands before focusing attention for the first time on AOI's.

According to Table 3, it was seen a significant difference in the number of fixations prior to the first fixation on the strong brand in relation to the weak brand. The average number of fixations in the strong brand was 11.66 and in the weak brand 17.43.

Basically, this variable enables a better understanding of the history of the visual attention of each participant in stimuli before the visual attention to the brand, allowing us to understand the differences between strong and weak brand. It also allows extrapolating some additional evidence regarding the visual behavior, mainly related to the idea that the number of prior fixations identifies a mapping pattern of the stimulus of a subject exposed to a visual communication.

Additionally, it enables the quantification of the relative interest of an individual between the brand and the rest of the information contained in the stimuli. Although it does not explain the greater or lesser relative interest, it assists in the discussion proposed in the introduction. Table 3 shows that, in the extreme, some individuals have made more than 35 fixations prior to fixation in brands, while others quickly had their visual attention attracted to the brand. In the case of strong brand, the faster process involved only two previous fixations, and the minimum number found for the weak brand was 7 prior fixations.

The same tests for normality (Kolmogorov-Smirnov and Shapiro-Wilk) and to assess the significance of differences of means (Wilcoxon) were applied.
The $p$-value $=0.000<0.05$ confirmed the statistical validity of the difference of $49.48 \%$ of more attention to the weak brand for fixations prior to the first fixation.

This means that a subject exposed to a visual communication stimulus tends to focus more attention on other regions when exposed to weak brands, exposing the possibility of significant differences in the selective attention behavior between a strong brand and a weak brand.

\subsection{Hypothesis 3}

H3 of this research was defined as: "The total duration of time devoted by each individual for areas linked to strong brand in the set of images shown will be faster than the total duration of time devoted by each individual to areas linked the weak brand". The Total Visit Time is a leading indicator of the higher incidence of visual attention in the set of tests proposed, since it allows the precise identification of the total time that individuals have devoted to the AOI's of each brand.

According to Table 4, there was a significant difference in the total visit time between weak and strong brands. In the sum of times, participants spent on average 1.34 seconds on the strong brand versus only 0.74 seconds on the weak brand.

The same tests for normality (Kolmogorov-Smirnov and Shapiro-Wilk) and to assess the significance of the differences of means (Wilcoxon) were applied. The $\mathrm{p}$-value $=0.000<0.05$ confirmed the statistical validity of the difference of $81 \%$ of more attention to the strong brand.

Table 2. Descriptive statistics of time for the $1^{\text {st }}$ fixation.

\begin{tabular}{lcccc}
\hline & $\begin{array}{c}\text { Minimum } \\
\text { (seconds) }\end{array}$ & $\begin{array}{c}\text { Maximum } \\
\text { (seconds) }\end{array}$ & $\begin{array}{c}\text { Mean } \\
\text { (seconds) }\end{array}$ & $\begin{array}{c}\text { SD } \\
\text { (seconds) }\end{array}$ \\
\hline First fixation (strong brand) & 0.39 & 12.77 & 3.21 & 2.59 \\
First fixation (weak brand) & 1.78 & 13.62 & 5.68 & 2.88 \\
\hline
\end{tabular}

$\mathrm{SD}=$ Standard Deviation.

Table 3. Descriptive statistics of the number of fixations prior to $1^{\text {st }}$ fixation.

\begin{tabular}{lcccc}
\hline & $\begin{array}{c}\text { Minimum } \\
\text { (n) }\end{array}$ & $\begin{array}{c}\text { Maximum } \\
\text { (n) }\end{array}$ & $\begin{array}{c}\text { Mean } \\
\text { (n) }\end{array}$ & $\begin{array}{c}\text { SD } \\
\text { (n) }\end{array}$ \\
\hline Number of prior fixations (strong brand) & 2 & 37 & 11.66 & 8.23 \\
Number of prior fixations (weak brand) & 7 & 45 & 17.43 & 8.96 \\
\hline
\end{tabular}

$\mathrm{SD}=$ Standard Deviation; $\mathrm{n}=$ number.

Table 4. Descriptive statistics for the total visit time.

\begin{tabular}{lcccc}
\hline & $\begin{array}{c}\text { Minimum } \\
\text { (seconds) }\end{array}$ & $\begin{array}{c}\text { Maximum } \\
\text { (seconds) }\end{array}$ & $\begin{array}{c}\text { Mean } \\
\text { (seconds) }\end{array}$ & $\begin{array}{c}\text { SD } \\
\text { (seconds) }\end{array}$ \\
\hline First fixation (strong brand) & 0.0 & 4.98 & 1.34 & 0.89 \\
First fixation (weak brand) & 0.0 & 3.14 & 0.74 & 0.75 \\
\hline
\end{tabular}

$\mathrm{SD}=$ Standard Deviation. 


\section{Discussions and conclusions}

The research objectives of analyzing how a brand with greater brand equity affects selective visual attention in the context of young consumers and alcoholic beverages were achieved and the results have important lessons learned for managerial implications, particularly to Operation and Production management, presented next.

Firstly, since a significant difference between brands with respect to visual attention was observed, some practical and important conclusions for marketing can be drawn. The first lesson is that there is the possibility that even if a campaign for a weak or lesser-known brand is designed, the first interaction between the target consumer of the stimulus and the visual communication in the AOI region has a disproportionate importance in relation to other AOIs related to the brand.

Therefore, these results may help to develop more effective marketing campaigns, as they allow the structuring of communications that appreciate the first interaction. This is the exact moment that different brands are equal for a given consumer. For a brand with strong brand equity, this fact may represent a focus of attention for being a critical and vulnerable point of visual communication. For a brand considered weak, it represents a new opportunity to improve its advertising campaigns, the exposure of a brand on a supermarket shelf, among other endless possibilities linked to the design of a new product, the choice of colors etc. The study may help to develop more effective marketing campaigns and products, providing the consumers a better experience.

Secondly, the results also contribute to an ethical discussion expanded to other sectors of society on markets that clearly represent negative externalities in increased consumption such as tobacco, illegal drugs, among others. The contribution extended even to the consumption of lawfully marketed drugs that use marketing strategies similar to those used by alcoholic beverage industries.

Thirdly, it was seen that, when applying neuroscience to marketing, it allows marketing researchers to have a better understanding of the degree of abstraction present in the minds of customers and the role of emotions in decision-making and enables the development of more effective methods for triggering these emotions, also according to Vashishta \& Balaji (2012) conclusions. Thus, eye-tracking, the method here employed, can be used to better understand the effect that psychological phenomena and emotions have on purchasing decisions and to provide a better assessment of the effectiveness of marketing programs.

Fourthly, the results of this research also have important consequences for Production Management and Operations, particularly behaviors that generate errors in the machinery operation, especially visual and cognitive behavior for warnings and alerts in factories aiming to improve safety at work. Safety Production is a seriously recurrent problem in modern industry engineering. The results here obtained allowed us to conclude that dual cognitive processing interferes in an impactful way in visual and unconscious attention, allowing to shed light on themes related to visual attention, neural processing of perception of danger and attention to warnings. Warning signs and safety signs are very important for work safety in various factories, civil construction, mining and many other locations with machinery operations that recurrently generate work accidents (Ma et al., 2010, 2011). Understanding cognitive processing will be one of the most important bases for improving safety at work (Zhou et al., 2013a).

This neuromarketing research comes within the context of a new line of research in the field of Production and Operations with the potential to bring several important insights for increased productivity, efficient and less inventory production, safety at work, ergonomic development and time and movement studies; the application of neuromarketing and cognitive neuroscience tools to production. With a broader line, encompassing neuromarketing, neuroeconomics and other multidisciplinary disciplines linking neurofeedback and biofeedback tools traditionally used in medicine, some scholars are naming this new area as the Neuro Industrial Engineering or Neuro-IE (Zhou et al., 2013b; Ma et al., 2012a).

Therefore, a better understanding of the relationship between dual cognitive processing, selective visual attention and brand equity is a way to decipher important issues of marketing management, consumer behavior, decision-making process and the neural mechanisms of attentional control that are not well answered and that have many applications on Operations management. The present study aimed to analyze how a brand with greater brand equity power affects selective visual attention in a very specific context: assessing the impact of the brand on young consumers in a product line that raises ethical discussions. This better understanding of a visual stimulus is in pace with Achrol \& Kotler's (2012) proposition, that mentions that it is important to reach consumers' need satisfaction by understanding their experiences filtered through their senses.

The goal of understanding the impacts of the dual cognitive system and its insertion in the discussion of alcohol consumption among young people has also been achieved, bringing new analysis of how these mechanisms of implicit association in System 1 operate from the point of view of selective visual attention. In the discussion of dual cognitive processing (Barrett et al., 2004; Evans, 2008; Kahneman, 2011), the findings strengthen the understanding of differences between System 1 and System 2. 
Smith \& DeCoster (2000) identified that the associative effect is much stronger and more present than imagined. In this specific context of discussion, the findings show that these effects are long-term, since it could be assumed that the young adults included in this experiment had continuous exposure as children to marketing stimuli from manufacturers of alcoholic beverages and did not have enough time to mature their own perceptions about the quality of different brands of beer.

Among the study limitations, the images selected have other information not exclusively on brands involved in the search and visual attention that may have been influenced by these other information. Further studies with different stimuli, different sectors and different brands will be extremely welcome to broaden the understanding of the real influence in the results that this limitation represents.

\section{Acknowledgements}

This research was supported by the Sao Paulo Research Foundation (FAPESP Brazil, 2014/22576-4).

\section{References}

Achrol, R. S., \& Kotler, P. (2012). Frontiers of the marketing paradigm in the third millennium. Journal of the Academy of Marketing Science, 40(1), 35-52. http:// dx.doi.org/10.1007/s11747-011-0255-4.

Ait Hammou, K. A., Galib, M. H., \& Melloul, J. (2013). The contributions of neuromarketing in marketing research. Journal of Management Research, 5(4), 20-33. http:// dx.doi.org/10.5296/jmr.v5i4.4023.

Auty, S., \& Lewis, C. (2004). Exploring children's choice: the reminder effect of product placement. Psychology and Marketing, 21(9), 697-713. http://dx.doi.org/10.1002/ mar.20025.

Bao, Y., Fern, E. F., \& Sheng, S. (2007). Parental style and adolescent influence in family consumption decisions: an integrative approach. Journal of Business Research, 60(7), 672-680. http://dx.doi.org/10.1016/j. jbusres.2007.01.027.

Barkin, E. (2013). The prospects and limitations of neuromarketing. CRM Magazine, 17(7), 46-50.

Barrett, L. F., Tugade, M. M., \& Engle, R. W. (2004). Individual differences in working memory capacity and dual-process theories of the mind. Psychological Bulletin, 130(4), 553-573. http://dx.doi.org/10.1037/00332909.130.4.553. PMid:15250813.

Boffetta, P., \& Hashibe, M. (2006). Alcohol and cancer. The Lancet. Oncology, 7(2), 149-156. http://dx.doi. org/10.1016/S1470-2045(06)70577-0. PMid:16455479.

BrandAnalytics. (2014). Marcas mais valiosas do Brasil em 2014. Retrieved in 2012, December 18, from http:// www.brandanalytics.com.br/imagens/top50Brasil.pdf
Chandon, P. (2002). Do we know what we look at? An eye-tracking study of visual attention and memory for brands at the point of purchase. Fontainebleau: INSEAD. Working Paper.

Chartrand, T. L., Huber, J., Shiv, B., \& Tanner, R. (2008). Nonconscious goals and consumer choice. The Journal of Consumer Research, 35(2), 189-201. http://dx.doi. org/10.1086/588685.

Chernatony, L., \& McDonald, M. (2003). Creating powerful brands in consumer service and industrial markets (3rd ed.). Oxford: Butterworth Heinemann.

Cortez-Pinto, H., Gouveia, M., Pinheiro, L. S., Costa, J., Borges, M., \& Carneiro, A. V. (2010). The burden of disease and the cost of illness attributable to alcohol drinking - results of a national study. Alcoholism, Clinical and Experimental Research, 34(8), 1442-1449. http://dx.doi.org/10.1111/j.1530-0277.2010.01229.x. PMid:20528821.

Deppe, M., Schwindt, W., Kramer, J., Kugel, H., Plassmann, H., Kenning, P., \& Ringelstein, E. B. (2005a). Evidence for a neural correlate of a framing effect: bias-specific activity in the ventromedial prefrontal cortex during credibility judgments. Brain Research Bulletin, 67(5), 413-421. http://dx.doi.org/10.1016/j.brainresbull.2005.06.017. PMid:16216688.

Deppe, M., Schwindt, W., Kugel, H., Plassmann, H., \& Kenning, P. (2005b). Non-linear responses within the medial prefrontal cortex reveal when specific implicit information influences economic decision making. Journal of Neuroimaging, 15(2), 171-182. http://dx.doi. org/10.1111/j.1552-6569.2005.tb00303.x. PMid:15746230.

Deppe, M., Schwindt, W., Pieper, A., Kugel, H., Plassmann, H., Kenning, P., Deppe, K., \& Ringelstein, E. B. (2007). Anterior cingulate reflects ssceptibility to framing during atractiveness evaluation. Neuroreport, 18(11), 1119-1123. http://dx.doi.org/10.1097/WNR.0b013e3282202c61. PMid:17589310.

Esch, F. R., Möll, T., Schmitt, B., Elger, C. E., Neuhaus, C., \& Weber, B. (2012). Brands on the brain: what happens neurophysiologically when consumer process and evaluate brands? Journal of Consumer Psychology, 22(1), 75-85. http://dx.doi.org/10.1016/j.jcps.2010.08.004.

Evans, J. S. B. T. (2008). Dual-processing accounts of reasoning, judgment, and social cognition. Annual Review of Psychology, 59(1), 255-278. http://dx.doi.org/10.1146/ annurev.psych.59.103006.093629. PMid:18154502.

Fafrowicz, M., \& Marek, T. (2007). Quo vadis, neuroergonomics? Ergonomics, 50(11), 1941-1949. http://dx.doi.org/10.1080/00140130701676096. PMid:17972211.

Fitzsimons, G. J., Hutchinson, J. W., Williams, P., Alba, J. W., Chartrand, T. L., Huber, J., Kardes, F. R., Menon, G., Raghubir, P., Russo, J. E., Shiv, B., \& Tavassoli, N. T. (2002). Non-conscious influences on consumer choice. Marketing Letters, 13(3), 269-279. http://dx.doi. org/10.1023/A:1020313710388. 
Fournier, S. (1998). Consumer and their brands: developing relationship theory in consumer research. The Journal of Consumer Research, 24(4), 343-353. http://dx.doi. org/10.1086/209515.

Hillenbrand, P., Alcauter, S., Cervantes, J., \& Barrios, F. (2013). Better branding: brand names can influence consumer choice. Journal of Product and Brand Management, 22(4), 300-308. http://dx.doi.org/10.1108/ JPBM-04-2012-0120.

Hoeffler, S., \& Keller, K. L. (2003). The marketing advantages of strong brands. Brand Management, 10(6), 421-445. http://dx.doi.org/10.1057/palgrave.bm.2540139.

Instituto Brasileiro de Opinião Pública e Estatística - IBOPE. (2012). Anunciantes - 30 maiores - $1^{\circ}$ semestre de 2012. Conhecimento. Retrieved in 2012, December 18, from http://www.ibope.com.br/pt-br/conhecimento/TabelasMidia/ investimentopublicitario/Paginas/ANUNCIANTES-30MAIORES-1-SEMESTRE-2012.aspx

Junghöfer, M., Kissler, J., Schupp, H. T., Putsche, C., Elling, L., \& Dobel, C. (2010). A fast neuralsignature of motivated attention to consumer goods separetes the sexes. Frontiers in Human Neuroscience, 4, 1-11. http:// dx.doi.org/10.3389/fnhum.2010.00179. PMid:21079751.

Kahneman, D. (2011). Thinking, fast and slow. New York: Farrar, Straus and Giroux.

Keller, K. L. (2009). Building strong brands in a modern marketing communications environment. Journal of Marketing Communications, 15(2-3), 139-155. http:// dx.doi.org/10.1080/13527260902757530.

Kent, R. J., \& Allen, C. T. (1994). Competitive interference effects in consumer memory for advertising: the role of brand familiarity. Journal of Marketing, 58(3), 97105. http://dx.doi.org/10.1177/002224299405800307.

Kotler, P., \& Keller, K. L. (2009). Marketing management. Upper Saddle River: Pearson Prentice Hall.

Lindstrom, M. (2008). Buyology: truth and lies about why we buy. New York: Doubleday.

Ma, Q., Bian, J., Ji, W., Tang, Q., \& Xu, Q. (2011). Research on warnings with new thought of Neuro-IE. Procedia Engineering, 26, 1633-1638. http://dx.doi.org/10.1016/j. proeng.2011.11.2348.

Ma, Q., Ji, W., Fu, H., \& Bian, J. (2012a). Neuro-industrial engineering: the new stage of modern IE - from the human oriented perspective. International Journal of Services Operations and Informatics, 7(2-3), 150-166. http://dx.doi.org/10.1504/IJSOI.2012.051398.

Ma, Q., Jin, J., \& Wang, L. (2010). The neural process of hazard perception and evaluation for warning signal words: evidence from event-related potentials. Neuroscience Letters, 483(3), 206-210. http://dx.doi.org/10.1016/j. neulet.2010.08.009. PMid:20705118.

Ma, Q., Shang, Q., Fu, H. J., \& Chen, F. Z. (2012b). Mental workload analysis during the production process: EEG and GSR activity. Applied Mechanics and Materials,
220-223, 193-197. http://dx.doi.org/10.4028/www. scientific.net/AMM.220-223.193.

Martinez, P. (2011). The consumer mind: Brand perception and the implication for marketers. London: Kogan Page.

McClure, S. M., Li, J., Tomlin, D., Cypert, K. S., Montague, L. M., \& Montague, P. R. (2004). Neural correlates of behavioral preference for culturally familiar drinks. Neuron, 44(2), 379-387. http://dx.doi.org/10.1016/j. neuron.2004.09.019. PMid:15473974.

Moore, E. S. (2004). Children and the changing world of advertising. Journal of Business Ethics, 52(2), 161-167. http://dx.doi.org/10.1023/B:BUSI.0000035907.66617.f5.

Nairn, A., \& Fine, C. (2008). Who's messing with my mind? The implications of dual-process models for the ethics of advertising to children. International Journal of Advertising, 27(3), 447-470. http://dx.doi.org/10.2501/ S0265048708080062.

Parasuraman, R., \& Wilson, G. F. (2008). Putting the brain to work: neuroergonomics past, present and future. Human Factors, 50(3), 468-474. http://dx.doi. org/10.1518/001872008X288349. PMid:18689055.

Plassman, H., Kenning, P., \& Ahlert, D. (2007). Why companies should make their customers happy: the neural correlates of customer loyalty. Advances in Consumer Research. Association for Consumer Research (U. S.), 34, 735-739.

Plassmann, H., Ramsoy, T. Z., \& Milosavljevic, M. (2012). Branding the brain: a critical review and outlook. Journal of Consumer Psychology, 22(1), 18-36. http://dx.doi. org/10.1016/j.jcps.2011.11.010.

Pöschl, G., \& Seitz, H. K. (2004). Alcohol and cancer. Alcohol and Alcoholism (Oxford, Oxfordshire), 39(3), 155-165. http://dx.doi.org/10.1093/alcalc/agh057. PMid:15082451.

Ramis, T. R., Mielke, G. I., Habeyche, E. C., Oliz, M. M., Azevedo, M. R., \& Hallal, P. C. (2012). Tabagismo e consumo de alcool em estudantes universitários: prevalência e fatores associados. Revista Brasileira de Epidemiologia, 15(2), 376-385. http://dx.doi.org/10.1590/ S1415-790X2012000200015. PMid:22782103.

Ratnayake, N., Broderick, A. J., \& Mitchell, R. L. C. (2010). A neurocognitive approach to brand memory. Journal of Marketing Management, 26(13-14), 1295-1318. http:// dx.doi.org/10.1080/0267257X.2010.522531.

Reimann, M., Castaño, R., Zaichkowsky, J., \& Bechara, A. (2012a). How we relate to brands: psychological and neurophysiological insigths into consumer-brand relationships. Journal of Consumer Psychology, 22(1), 128-142. http://dx.doi.org/10.1016/j.jcps.2011.11.003.

Reimann, M., Castaño, R., Zaichkowsky, J., \& Bechara, A. (2012b). Novel versus familiar brands: an analysis of neurophysiology, response latency, and choice. Marketing Letters, 23(3), 745-759. http://dx.doi.org/10.1007/ s11002-012-9176-3. 
Samson, A., \& Voyer, B. G. (2012). Two minds, three ways: dual system and dual process models in consumer psychology. Ams Review, 2(2-4), 48-71. http://dx.doi. org/10.1007/s13162-012-0030-9.

Santos, J. P., Seixas, D., Brandão, S., \& Moutinho, L. (2011). Investigating the role of the ventromedial prefrontal cortex in the assessment of brands. Frontiers in Neuroscience, 5, 1-8. http://dx.doi.org/10.3389/ fnins.2011.00077. PMid:21687799.

Santos, R. O. J., Oliveira, J. H. C., Rocha, J. B., \& Giraldi, J. M. E. (2015). Eye tracking in neuromarketing: a research agenda for marketing studies. International Journal of Psychological Studies, 7(1), 32-42. http:// dx.doi.org/10.5539/ijps.v7n1p32.

Schaefer, M., \& Rotte, M. (2007a). Favorite brands as cultural objetcs modulate reward circuit. Neuroreport, 18(2), 141145. http://dx.doi.org/10.1097/WNR.0b013e328010ac84. PMid:17301679.

Schaefer, M., \& Rotte, M. (2007b). Thinking on luxury or pragmatic brand products: brain responses to different categories of culturally based brands. Brain Research, 1165, 98-104. http://dx.doi.org/10.1016/j. brainres.2007.06.038. PMid:17655834.

Schaefer, M., Berens, H., Heinze, H. J., \& Rotte, M. (2006). Neural correlates of culturally familiar brands of car manufacturers. NeuroImage, 31(2), 861-865. http://dx.doi.org/10.1016/j.neuroimage.2005.12.047. PMid:16487728.

Siefert, C., Gallent, J., Jacobs, D., Levine, B., Stipp, H., \& Marci, C. (2008). Biometric and eye-trackinginsigths into the efficiency of information processing of television advertising during fast-forward viewing. International Journal of Advertising, 27(3), 425-446. http://dx.doi. org/10.2501/S0265048708080050.

Sloman, S. A. (1996). The empirical case for two systems of reasoning. Psychological Bulletin, 119(1), 3-22. http:// dx.doi.org/10.1037/0033-2909.119.1.3.

Smith, E. R., \& DeCoster, J. (2000). Dual-process models in social and cognitive psychology: conceptual integration and links to underlying memory systems. Personality and Social Psychology Review, 4(2), 108-131. http:// dx.doi.org/10.1207/S15327957PSPR0402_01.

Solnais, C., Andreu-Perez, J., Sanchez-Fernandez, J., \& Andreu-Abela, J. (2013). The contribution of neuroscience to consumer research: a conceptual framework and empirical review. Journal of Economic Psychology, 36, 68-81. http://dx.doi.org/10.1016/j.joep.2013.02.011.

Sreedevi, V., Jayasree, K. V., \& Auguskani, P. L. (2013). Neuromarketing: an effective marketing strategy. International Journal of Marketing and Technology, 3(6), 63-70.

Stewart, A. J., Pickering, M., \& Sturt, P. (2004). Using eye movements during reading as an implicit measure of the acceptability of brand extensions. Applied Cognitive Psychology, 18(6), 697-709. http://dx.doi.org/10.1002/ acp. 1024 .
Strack, F., \& Deutsch, R. (2004). Reflective and impulsive determinants of social behavior. Personality and Social Psychology Review, 8(3), 220-247. http://dx.doi. org/10.1207/s15327957pspr0803_1. PMid:15454347.

Theeuwes, J. (2010). Top-down and botton-up control of visual selection. Acta Psychologica, 135(2), 7799. http://dx.doi.org/10.1016/j.actpsy.2010.02.006. PMid:20507828.

Toates, F. (2006). A model of the hierarchy of behaviour, cognition, and consciousness. Consciousness and Cognition, 15(1), 75-118. http://dx.doi.org/10.1016/j. concog.2005.04.008. PMid:15996485.

Ülger, G., \& Ülger, B. (2012). Children in family purchase decision-making: children's role in food product purchases from mothers' point of view. Journal of Marketing Communications, 18(4), 297-320. http://dx.doi.org/1 $0.1080 / 13527266.2010 .528994$.

Vashishta, D. S., \& Balaji, B. (2012). Social cognitive neuroscience, marketing persuasion and customer relations. Procedia: Social and Behavioral Sciences, 65, 1033 1039. http://dx.doi.org/10.1016/j.sbspro.2012.11.238.

Venkatraman, V., Clithero, J. A., Fitzsimons, G. J. E., \& Huettel, S. (2012). New scanner data for brand marketers: how neuroscience can help better understand differences in brand preferences. Journal of Consumer Psychology, 22(1), 143-153. http://dx.doi.org/10.1016/j. jcps.2011.11.008.

Wedel, M., \& Pieters, R. (2000). Eye fixations on advertisements and memory for brands: a model and findings. Marketing Science, 19(4), 297-312. http:// dx.doi.org/10.1287/mksc.19.4.297.11794.

Wind, Y. (2005). Marketing as an engine of business growth: a cross-functional perspective. Journal of Business Research, 58(7), 863-873. http://dx.doi.org/10.1016/j. jbusres.2004.01.002.

Winer, R. S. (2009). New communications approaches in marketing: issues and research directions. Journal of Interactive Marketing, 23(2), 108-117. http://dx.doi. org/10.1016/j.intmar.2009.02.004.

Yoo, B., \& Donthu, N. (2001). Developing and validating a multidimensional consumer based brand equity scale. Journal of Business Research, 52(1), 1-14. http://dx.doi. org/10.1016/S0148-2963(99)00098-3.

Zhou, X., Chen, M., Wang, X., \& Wang, L. (2013a). The theorical analysis on cognitive process of the safety signs based on Neuro-IE. Applied Mechanics and Materials, 319, 286-291. http://dx.doi.org/10.4028/www.scientific. net/AMM.319.286

Zhou, X., Wang, L., \& Hu, Y. (2013b). Neuro-industrial engineering: research and practice. Applied Mechanics and Materials, 268-270, 2022-2025. http://dx.doi. org/10.4028/www.scientific.net/AMM.268-270.2022.

Zurawicki, L. (2010). Neuromarketing: exploring the brain of the consumer. Heidelberg: Springer. http://dx.doi. org/10.1007/978-3-540-77829-5. 